\title{
DÓCIL, OBEDIENTE E LABORIOSO: os múltiplos olhares sobre o (i)migrante ideal para o Brasil
}

\author{
Reinaldo Benedito Nishikawa*
}

\begin{abstract}
RESUMO: Durante os séculos XIX e XX, o processo de imigração e colonização para todo o país passava por uma série de prerrogativas e discussões de ordem política, econômica, moral, religiosa e cultural. Afinal, quem deveria vir ao Brasil e formar um corpo de trabalhadores destinados a construir um país em desenvolvimento? Sobre essa base, múltiplos personagens foram ganhando contornos e se subvertendo de acordo com os interesses divergentes e convergentes. Sobre esse olhar, europeus, asiáticos, africanos e nacionais, redimensionaram seu papel como mão-de-obra ao longo do tempo e do espaço. Assim, nesse artigo, buscávamos apresentar os múltiplos olhares sobre o imigrante ideal na construção do nosso país.
\end{abstract}

PALAVRAS-CHAVE: Imigração; Colonização; Multiplicidade étnica.

\section{Docile, obedient and industrious: the multiple looks on ideal immigrant to Brazil}

\begin{abstract}
During the 19th and 20th centuries, the process of immigration and colonization for the entire country was passing through a lot of prerogatives and discussions of a political, economic, moral, religious and cultural. After all, who should come to Brazil and form a body of employees intended to build a developing country? On this basis, multiple characters were gaining contours and if subverting in accordance with the differing and convergent interests. About this look, Europeans, Asians, Africans and national transformed its role as the workforce over time and space. Thus, in this article, we've been trying to show the multiple perspectives on the ideal immigrant for our country building .
\end{abstract}

KEYWORDS: Immigration; Colonization; Ethnic multiplicity.

\section{Dócil, obediente y trabajador: \\ los múltiples puntos de vista sobre la inmigrante ideal para Brasil}

RESUMEN: Durante los siglos XIX y XX, el proceso de inmigración y colonización de todo el país estaba puesto en el marco de una serie de prerrogativas y discusiones de orden político, económico, moral, religioso y cultural. Al fin, ¿quién debe venir a Brasil y formar un cuerpo de empleados destinados a construir un país en desarrollo? Sobre esta base, se forman las figuras de varios personajes que se subvierten en conformidad con los intereses divergentes y convergentes. Desde este punto de vista, los europeos, asiáticos, africanos y nacionales, redimensionaron su papel como fuerza de trabajo a lo largo del tiempo y en el espacio. Así, en este artículo, buscamos presentar las múltiples perspectivas sobre el inmigrante ideal para construir nuestro país.

PALABRAS CLAVE: inmigración; colonización; multiplicidad étnica.

\footnotetext{
* Docente do Instituto Federal do Paraná, Pós doutorando em História pela Universidade Estadual de Londrina e Doutor em História Econômica - USP. Contato: Instituto Federal do Paraná - Campus Londrina, R. João XXIII, 600 - CEP: 86060-370, Judith, Londrina - PR, Brasil. E-mail: reinaldo.nishikawa@ifpr.edu.br.
} 
Desde que o trabalho escravo no Brasil começou a mostrar sinais de cansaço, uma série de projetos foram propostos a fim de sanar tal problema. A pressão inglesa pelo fim da escravidão, de certa forma, ajudou muito a tomada de decisão nas cortes do nosso país. Bem verdade é que a discussão em torno da mão-de-obra para o Brasil ganhou diversos contornos ao longo de todo o processo histórico de colonização.

Do século XVI ao XVIII a mão-de-obra indígena e posteriormente africana ficavam confinadas no pensamento de que era um mal necessário, pois não havia outra possibilidade de exploração sem esses trabalhadores forçados a desempenhar um trabalho sub-humano. Nessa injusta disputa, o africano acabou por suportar os maiores excessos em nome de uma série de justificativas e explicações de ordem religiosa e científica. As discussões em torno da pureza das raças e de sua classificação, garantiriam a inferioridade racial de negros, indígenas e asiáticos.

Da purificação e domesticação, do caráter divino e recuperador até questões como o tamanho da caixa craniana foram utilizadas para justificar a superioridade de uma etnia sobre outra. Segundo Lilia Moritz Schwarcz, os estudos de antropologia cultural, ajudaria a explicar a hierarquia de raças. Para os evolucionistas sociais, a cultura teria se desenvolvido em estados sucessivos, caracterizados por organizações econômicas e sociais específicas, ou seja, o conjunto da humanidade teria que passar pelos mesmos estágios de processo evolutivo.

O método comparativo, por outro lado, funcionava como princípio orientador dos trabalhos, já que se supunha que cada elemento poderia ser separado do seu contexto original, e dessa maneira inserido em uma determinada fase ou estágio da humanidade. Dessa forma, entendia-se o progresso como obrigatório e restituía a noção de humanidade única. Entretanto, tal concepção não pode ser entendida de maneira tão superficial, afinal, não se pode olhar um grupo social e associar determinadas características físicas, culturais, sociais para todos.

(...) ser membro de uma mesma cultura não significa ter conhecimento idêntico. Pessoas de uma mesma comunidade e até de uma mesma família podem ter ideias diferentes sobre crenças culturais, habilidades diferentes nas práticas cotidianas e estratégias diferentes para interpretar e resolver problemas. [...] A língua nos fornece rótulos que muitas vezes são aceitos como dados. Falamos de 'americanos', 'italianos', 'japoneses', como se fossem grupos monolíticos ${ }^{1}$.

Criar-se-ia assim, um determinismo racial que permitiria uma conotação pessimista em relação a imigração e, por consequência, a miscigenação. Esse determinismo compreendia que as raças eram fenômenos imutáveis e a miscigenação entendida como algo errado. Assim 
houve um "enaltecimento" dos tipos "puros" e a mestiçagem era um sinônimo de degeneração racial e social.

Para os evolucionistas sociais, os homens seriam "desiguais" entre si, ou melhor, hierarquicamente desiguais em seu desenvolvimento global. Já para os darwinistas sociais, a humanidade estaria dividida em espécies para sempre marcadas pela "diferença", e em raças cujo potencial seria ontologicamente diverso.

O modelo racial servia (no Brasil) para explicar as diferenças e hierarquias, mas, feitos certos rearranjos teóricos, não impedia pensar na viabilidade de uma nação mestiça. As discussões teóricas em torno da raça e racismo, devem ser compreendidas dentro do contexto nacional nos finais do século XIX e início do XX. Se, por um lado, a potencialidade da imigração europeia, desejada como um meio de civilizar o país, de outro, a imigração asiática, refutada no século XIX com os chineses e fortalecida com os japoneses no século XX, demostram um certo arranjo entre as teorias racistas e as necessidades econômicas.

Nesse contexto, a Europa passava por uma série de mudanças e transformações. O crescimento populacional era proporcionalmente inverso a demanda de trabalhadores devido as intensas mecanizações, tanto na cidade quanto no campo. As disputas políticas que ocorriam em boa parte do mundo, as crises econômicas como resultado de um longo processo capitalista, as lutas trabalhistas e a procura por novos mercados, permearam todo o século XIX e início do $\mathrm{XX}^{2}$.

No Brasil, o imenso território que em grande medida não estava ocupado tornou-se um atrativo para um grande número de imigrantes que buscavam, de alguma forma, um recomeço. Nunca é demais relembrar que a ideia representada de "vazio" para o século XIX significava que os indígenas existentes no Brasil, não faziam parte da contabilidade do povoamento. Em boa medida, o sul do Brasil, descortinado como uma nova possibilidade de imigração, forjou de diversas maneiras, uma nova Europa para esses trabalhadores. Mas que trabalhadores? Quem deveria imigrar para o Brasil? Sob quais condições e interesses foram forjados a ideia de imigrante ideal? Não havia mão-de-obra nacional disponível para esses ofícios? Era necessário voltar os olhos para fora?

De nacionais a africanos e de europeus a asiáticos, o olhar referente a quem deveria povoar essa nova região foi se alterando de acordo com outros interesses e novas necessidades. De certa maneira, essa discussão foi se alimentando de acordo com o próprio processo de imigração e de discussão das necessidades dessas novas mão-de-obra para o país.

Bem verdade é que, desde a colonização, os africanos foram a grande leva de imigrantes que aportaram ao Brasil, excetuando-se os portugueses. Apesar de trabalhadores 
forçados, foram imigrantes que durante certo tempo foram um "mal necessário" e de outra medida, um problema associado a civilização e modernidade.

Diversos autores se debruçaram para buscar compreender os mecanismos de atração e fixação de africanos no Brasil. Da violência física, da constituição de núcleos familiares para evitar repressões e de outros tantos meios. Mas desde o século XVIII até o final do XIX, apesar das críticas de abolicionistas e da pressão inglesa, o tráfico humano ainda continuo pelo simples motivo econômico. Era mais barato "comprar" a mão-de-obra.

No que se refere a mão-de-obra africana, o discurso em torno da escravidão também orbitava em duas fases distintas. A primeira reforçava o flagelo da escravidão e das duras condições impostas pelos traficantes e senhores de escravos que em nada lembrava os ideais liberais que estavam circulando no Brasil e no mundo. Nas palavras de Antônio Feijó:

(...) vergonhosa contradição com os princípios liberais que professamos, conservar homens escravos, perpetuamente: diga-se nessa ocasião tudo quanto os economistas, os filósofos, os filantropos, e o que tem religião têm escrito contra a mais absurda das iniquidades ${ }^{3}$.

O duro discurso de Feijó, que retratava os males da escravidão, era também contraposto com a perspectiva salvadora da mesma. Ou seja, graças a ela, o Brasil poderia se modernizar e alcançar o grau de civilidade que muitos desejavam. $\mathrm{O}$ olhar sobre a escravidão ganhava novos tons. Bernardo Pereira de Vasconcelos afirmou:

\footnotetext{
Sim, a civilização brasileira de lá veio, porque daquele continente veio o trabalhador robusto, o único que sob este céu (...) poderia ter produzido, como produziu, as riquezas que proporcionaram a nosso pais recursos para mandar seus filhos estudar nas academias e universidades da Europa, ali adquirirem os conhecimentos de todos os ramos do saber, os princípios da Filosofia do Direito, em geral, e do Direito Público Constitucional, que impulsionaram e apressaram a Independência e presidiram à organização consagrada na Constituição e noutras leis orgânicas, ao mesmo tempo fortalecendo a liberdade ${ }^{4}$.
}

A escravidão, como meio e fim para atingir a civilidade europeia, passava por determinados males decorrentes da transformação do homem em uma ferramenta de trabalho. É evidente que o negro escravizado não aceitou passivamente tal condição e muitos trabalhos se debruçaram para estudar a resistência em relação a sua condição. Mas o discurso em torno da escravidão sempre caminhou para um fim, cedo ou tarde.

O brigadeiro Cunha Matos defendia a substituição, através da agricultura, do trabalho escravo pelo trabalho livre. Apesar das discussões em torno dos ideais desejáveis, encontramos aqui, o princípio dessa substituição, jogando para o governo propor medidas capazes de assegurar o trabalho e substituir os escravos: 
Bom será, senhores, que para o Brasil venham pessoas brancas de todas as Nações, para contrabalancearem, neutralizarem e escusarem a raça preta, sempre perigosa pela sua imoralidade: bom será que venham os chineses e hindustanis pacíficos e agricultores industriosos: e ainda melhor será que ao tempo em que todos eles puserem o pé em terra, saibam que entre nós existe uma polícia ativa e severa contra os vadios, a qual não permite que no Império vegetem lazaronis estrangeiros e nacionais ${ }^{5}$.

O século XIX assistiu assim, em grande medida, por pressões externas, a discussão do uso de escravos no país. Apenas em 1850 o Brasil torna ilegal o tráfico de escravos, mas não a escravidão. Aqui podemos dizer que foi o momento chave para que as elites pendessem a balança para uma solução da possível falta de escravos no país. A resposta encontrada, no mesmo ano, foi a atração de outros braços para suprir a grande lavoura de um lado e a pequena propriedade de outro.

Mas quem viria ao país? Quase toda a América também passava pelas mesmas necessidades. Dos Estados Unidos à Argentina, a busca por mão de obra estrangeira era uma constante e cada país buscou atrativos para fixar esses trabalhadores em suas terras. Do outro lado do Atlântico, uma grande maioria de europeus estavam desempregados, enfrentando crises políticas e econômicas e podiam encontrar uma nova oportunidade na América.

A dinâmica plural das experiências vivenciadas pelos europeus, no decorrer do processo de expansão comercial, tornou transparente o caráter multifacetado das experiências humanas no planeta Terra, ao passo que as reações diversas dos indivíduos cristãos ocidentais aos outros demonstrariam as múltiplas possibilidades de exercício da individualidade ${ }^{6}$.

Foram esses debates em torno das experiências humanas que tornou possível a multiplicidade étnica que aportou em terras brasileiras. Se pensarmos nas políticas de imigração no período imperial, D. Pedro I já tinha intenção de continuar com a atração de imigrantes ao Brasil. Na Constituição de 1824, percebe-se o interesse de cuidar “(...) pessoalmente, pelo povoamento e pela exploração de novas regiões do Brasil por brancos não portugueses ${ }^{7} . "$ Nota-se claramente a predileção por europeus para povoar esse imenso território.

É possível perceber também uma visão oposta, no começo do XIX, entre a proposta feita por D. Pedro I e os interesses dos grandes proprietários de escravos que desejavam reforçar a escravidão negra. A reação foi feita a rigor. Nicolau de Campos Vergueiro, futuro senador, expõe sua contrariedade às políticas imigrantistas propostas pelo imperador, atendendo aos interesses dos grandes latifundiários. 
(...) chamar os colonos para fazê-los proprietários a custas de grandes despesas, é uma prodigalidade ostentosa, que não se compadece com o apuro de nossas finanças. $\mathrm{O}$ meu parecer, pois, é que se acabe o quanto antes com a enorme despesa que se está fazendo com eles, continuando-se o que parecer necessário para eles procurarem serviço ${ }^{8}$.

Mas essa não foi à única medida. Em 15 de dezembro de 1830, a Lei do Orçamento foi à contrapartida do senado para defender os interesses dos proprietários de terras. Essa lei suspendeu os créditos destinados à colonização estrangeira. O resultado dessa política para impedir o surgimento de colônias de estrangeiros teve um grande impacto, pois na década seguinte, nenhuma colônia surgiu no país, como ressalta Iotti:

De 1830 a 1840, o país atravessou um período de crise, que culminou com a abdicação de D. Pedro I, em 7 de abril de 1831. O Ato Adicional de 12 de agosto de 1834 que, entre outras coisas, criou a Regência Uma, constituiu uma tentativa de reformar a organização política e administrativa do Império, conferindo maior autonomia às províncias. Através dele, o governo central dividiu com as províncias "a obra da colonização, sem, no entanto, oferecer-lhes poderes precisos. Todas as terras livres pertenciam ao Império e as províncias não tinham condições para promover a colonização: nem meios, nem experiência ${ }^{9}$.

Destacam-se, entretanto, algumas leis que foram aprovadas nesse período que apontam uma tentativa, ao menos teórica, de regular a imigração e o trabalho estrangeiro. Segundo Iotti, temos em 13 de setembro de 1830 a aprovação de uma regulamentação referente ao trabalho no Brasil, no que tange ao contrato sobre prestações de serviços realizados por brasileiros e estrangeiros. A Lei $\mathrm{n}^{\mathrm{o}} 108$ de 11 de outubro de 1837 buscava regular os contratos de locação de serviços e, destacamos também, a Lei de Naturalização, aprovada em 23 de outubro de 1832, que tornava cidadão brasileiro os estrangeiros maiores de vinte e um ano e residentes no Brasil há, pelo menos, quatro anos.

Na década de 1840 um novo fôlego reiniciou as tentativas de buscar o imigrante europeu. Tal fator pode ser apontado por uma iniciativa do governo parlamentar brasileiro que transferia para as províncias às terras devolutas que poderiam ser destinadas à colonização, segundo a Lei $\mathrm{n}^{\circ}$ 514, artigo 16 de 28 de outubro de 1848 :

Art. 16. - A cada uma das Províncias do Império ficam concedidas no mesmo, ou em diferentes lugares de seu território, seis léguas em quadra de terras devolutas, as quais serão exclusivamente destinadas à colonização, e não poderão ser roteadas por braços escravos. Estas terras não poderão ser transferidas pelos colonos enquanto não estiverem efetivamente roteadas e aproveitadas, e reverterão aos domínios Provinciais se dentro de cinco anos os colonos respectivos não tiverem cumprido esta condição ${ }^{10}$.

Tal medida reforçou os interesses regionais, uma vez que ao transformar a imigração em um plano de ordem provincial, cada região buscou atrelar à vinda de imigrantes as 
necessidades mais proeminentes de sua atual conjuntura. No que tange à segunda metade do século XIX a conjuntura apresentou dois elementos centrais para se compreender o processo das políticas de imigração: a Lei n ${ }^{\circ} 581$ aprovada em 4 de setembro de 1850, tornava extinto o tráfico de escravos para o Brasil e a Lei n601 de 18 de setembro do mesmo ano, conhecida como Lei de Terras, que tornava a compra e a venda os únicos meios de acesso à terra no Brasil.

Muitos historiadores buscaram compreender os impactos que a lei de terras trouxe ao processo imigratório no Brasil e segundo Maria Petrone, a Lei de Terras:

(...) embora assegurasse certos recursos para os programas de colonização, pode ser interpretada como resultado da pressão dos grandes proprietários monocultores de café, que (...) pretendiam drenar a corrente de imigrantes para as suas fazendas, daí o interesse de que não mais se doassem terras para a criação de núcleos coloniais ${ }^{11}$.

Entretanto, é válido ressaltar que as políticas de terras acabaram se destinando a duas vertentes, a primeira visava amenizar a falta de mão-de-obra nas grandes lavouras devido ao fim do tráfico de escravos, onde o imigrante europeu substituiria gradativamente o iminente fim de negros escravizados no Brasil, a segunda vertente, visava construir núcleos colônias para suprir outro problema para o país, a falta de gêneros de primeira necessidade para o abastecimento do mercado interno.

Se a lei de terras foi um dos chamarizes encontrados para atrair esses trabalhadores, de outro lado, ficou em muitos discursos da época, a ideia de branqueamento que a imigração poderia trazer. Mas o que significava branquear o país? Muito mais do que a miscigenação, tem-se a ideia de branqueamento como um avanço em relação ao outro, no caso do Brasil, aos indígenas e principalmente aos africanos. Branquear era eliminar, pouco a pouco, qualquer traço daquilo que lembrava o atraso no processo de colonização brasileira.

Os fatos comprovam que o interesse dominante de boa parte dos deputados e fazendeiros acabou prevalecendo. Os principais argumentos acionados para justificar os critérios eram: a exigência de "altos" salários por parte dos nacionais, a escassez de braços e o melhor preparo do imigrante para o trabalho assalariado ou regime de colonato. Esse discurso acobertava a teoria de que o imigrante europeu era parcialmente superior e que o Brasil deveria urgentemente iniciar um processo de branqueamento da população, caso quisesse estar entre as nações ditas "civilizadas"

Mas não foi apenas o europeu que se inseria no quesito branco. A indesejada força de trabalho chinesa, consubstancializou naquilo que o diplomata japonês Sho Nemoto usou para denominar os "brancos" da Ásia. Ele "vendeu" a imagem de que os imigrantes japoneses eram os trabalhadores necessários e desejados para cumprir um papel no Brasil. 
O interesse do governo Meiji pela emigração dava-se em razão da sempre crescente população rural, que vinha-se tornando cada vez mais faminta e inquieta. A emigração era um 'tema constante nas discussões sobre a situação econômica do Japão e seu lugar no mundo', uma vez que ela tinha como objetivo aliviar as pressões sobre a terra e, ao mesmo tempo, criar colônias que cultivariam gêneros alimentícios que seriam reexportados para o Japão ${ }^{13}$.

Dessa forma, criou-se um olhar ambíguo sobre os trabalhadores que emigravam para o Brasil. Europeus e asiáticos dividiam opiniões e as qualidades e defeitos eram formulados de acordo com os interesses em questão. O diplomata Salvador Mendonça, em viagem aos Estados Unidos no final do século XIX, buscava observar de perto o trabalhador asiático para a vinda ao Brasil.

Nós que não podemos progredir sem imigração; que a não temos espontânea senão a portuguesa, infelizmente diminuta para nos trazer o remédio de que carecemos; que não somos ricos e que estamos ameaçados de nos africanizarmos; que nós em tais condições repilamos a raça que deve preparar a vinda do europeu no futuro, não só não é razoável, como é pior - é absurdo ${ }^{14}$.

Os chineses e japoneses se diferenciavam. Em primeiro lugar, pela necessidade e demanda no século XIX de chineses. Usados quase como escravos nos Estados Unidos, no Brasil essa mão de obra era alvo de controvérsias. O medo da miscigenação dos chineses, causavam pânico e a possibilidade de deteriorarem a construção da modernidade era latente. Os trabalhos de Lesser (2001) e Denzem (2005) já discutiram muito o "medo amarelo" e os discursos em torno dessa mão de obra.

Em discussão a respeito dos benefícios ou malefícios dos trabalhadores chineses, vários políticos discursaram sobre as vantagens, ou não de trazer esses imigrantes. Em um discurso entre o governo de Minas Gerais e proprietários de terras, o jornal $O$ Pharol, publicou a seguinte discussão:

Embora os membros da comissão acatassem o medo sinófobo da "mongolização", eles concordaram também que se o número de imigrantes fosse limitado a cem mil, eles acabariam por se abrasileirar: "Se o chim é de raça inferior à nossa, verá o universo, pela primeira vez, a absorção da raça superior, dez vezes mais numerosa, pela raça inferior?!!... se somos superiores ao chim, o que ganhamos? Se somos inferiores, o que perdemos?". Um outro grupo, esse da região amazônica, era de opinião que, "trancar as nossas portas aos asiáticos e aos africanos livres... e antihumanitário, pois nega [a eles] os benefícios da catequese e da civilização", ao mesmo tempo que postulava que os trabalhadores chineses não prejudicariam a sociedade brasileira porque "mortos ou vivos, [eles] sempre voltam para a China ${ }^{15}$.

No que tange aos imigrantes japoneses, apesar das tentativas tímidas do século XIX, apenas no início do XX (1908) que desembarcaram os primeiros imigrantes no Brasil. Nesse 
período, o país vivia as sombras da modernização e da industrialização. O crescimento dos movimentos operários também ajudaram a dar uma nova cara aos imigrantes europeus. Baderneiros, arruaceiros, comunistas! Apenas para se ter uma noção, no final do século XIX (1890-1900), os jornais de São Paulo apresentam cerca de 624 notícias de greve em todo o estado, nas primeiras décadas do século XX, salta-se para mais de 3.000.

Os olhos então voltam-se para os asiáticos "brancos", que teriam agora, a missão de serem obedientes, dóceis e laboriosos. Sobre a visita de Sho Nemoto ao Brasil para iniciar as relações comerciais, Lesser apresenta como o olhar sobre os asiáticos ganham novos contornos:

\begin{abstract}
A busca por mão-de-obra submissa casava-se bem com a afirmação nada sutil de Sho Nemoto, de que os japoneses eram os "brancos" da Ásia. Diferentemente de Tong King-sing, que com suas túnicas de seda e seu secretário afro-americano, Nemoto desembarcou trajando um terno ocidental. As elites brasileiras sentiram-se lisonjeadas com um artigo de primeira página publicado no Correio Paulistano, no qual Nemoto escreveu sobre seu "encantamento" com um país onde o japonês "imigrante pode perfeitamente se instalar", e onde "poderemos melhorar o nível de vida, obter propriedades, dar educação a nossos filhos e viver com alegria". Calcando-se no notável crescimento econômico que seu país vinha apresentando nas últimas décadas do século XIX, Nemoto vendeu a imagem dos imigrantes japoneses como sendo tudo o que os europeus não eram: quietos, trabalhadores e ansiosos por se tornarem brasileiros ${ }^{16}$.
\end{abstract}

Sho Nemoto aparece citado várias vezes nos jornais paulistas e tornou-se um importante porta-voz da imigração. Sua visita a São Paulo gerou diversas notícias, sempre elogiosas e respeitosas, nada lembrando as notícias feitas sobre os imigrantes chineses.

O importante trabalho do dr. Sho Nemoto foi há tempos já entregue ao governo do seu paiz, para que, depois de convenientemente estudado, tenha a sagração official. E pelo facto mesmo de não ter ainda transpirado, em consequência de não estar completo esse estudo, a opinião dos públicos poderes japonezes a respeito do futuro congraçamento do nosso paiz com aquella prospera região asiática, nada podemos adiantar sobre o assumpto, que a todos interessa, e principalmente à lavoura, que nisso vê um novo elemento do poderoso auxilio para os seus trabalhos ${ }^{17}$.

Para reforçar o medo europeu, Sylvio Romero, no livro O Allemanismo no sul do Brasil - seus perigos e os meios de os conjurar, escrito em 1906, descreve de modo vivaz, os perigos da imigração alemã no Brasil. Segundo os modelos de imigração que ocorriam no Brasil no final do século XIX e início do XX, eram de maior preocupação para o desenvolvimento do Brasil, alocar esses trabalhadores.

Não canso de repetir: tal systema póde ser optimo, e o é, por certo, do ponto de vista alemão; mas é péssimo, é perniciosíssimo, do ponto de vista brasileiro. Para se formar idéia exacta da gravidade do assumpto, mister é ter estudado diligentemente o povo germânico, conhecel-o bem no seu desenvolvimento histórico, e, acima de 
tudo, no seu assombroso progresso contemporâneo, nas industrias, na navegação, no commercio, na expansão que se sente escoar para colônias suas o excesso de sua população, que aumenta, a olhos visto, de fórma assustadora ${ }^{18}$.

Para reforçar suas ideias, Romero utiliza-se de uma vasta citação de pensadores, políticos, filósofos e literários que corroboram com sua tese. Em seu trabalho, demonstra uma arquitetura do imigrante alemão para dominar o país. Em linhas gerais, afirma Romero que:

Quem não apprehende a questão desta altura não logra conceber-lhe o alcance e não chega a formar a consciência clara de quanto ella tem de brilhante e esperançosa para allemães e de vergonhosa e humilhante para brasileiros ${ }^{19}$.

Sua tese é reforçada pelo expansionismo alemão, fruto do processo de unificação. "Em quatro annos, de 1884 a 1888, o império germânico, que até então não possuía um palmo de terra fóra da Europa - nos continentes longínquos, se fez a terceira potencia colonial do mundo" (idem). Os relatos do crescimento alemão, com o medo de que esses imigrantes ingressassem na vida política, levou Romero a temer o domínio alemão no país. Se pensarmos no que estava ocorrendo com os movimentos operários, essa tese, reforçava o problema que o imigrante europeu, antes desejado, poderia se tornar.

O discurso em torno do trabalhador ideal e imaginário se entrelaçavam com as práticas existentes, seja nas grandes lavouras ou nas pequenas propriedades. A ideia de dócil, laborioso e obediente foi utilizado em diversas vezes para caracterizar diversas etnias. Segundo Lesser:

Entre as elites, esse entrelaçamento dos conceitos de imigração, etnicidade e identidade nacional se expressava em um discurso que via como desejáveis certos grupos de imigrantes. Mesmo assim, esse discurso era pouco consistente, já que essas elites eram facilmente convencidas a mudar de ideia quanto a quais grupos eram mais “desejáveis" e "embranqueceriam” o país ${ }^{20}$.

Se o imigrante europeu era o portador da civilização, portanto, voltado a um projeto de nação no país, o imigrante asiático era uma solução barata e imediata e vista simplesmente como mão-de-obra e não como parte de um processo para povoar o país. Os brasileiros, segundo o Congresso do Sudeste, eram vistos como indolentes, preguiçosos e instáveis no trabalho. Ex-escravos, ingênuos não poderiam se adaptar ao trabalho e obedecer qualquer tipo de contrato, a menos que fossem ensinados previamente.

Se havia em quantidades suficientes esses braços, como coagi-los ao trabalho? Muitos acreditavam que deveriam criar leis para que obrigassem esses ociosos ao trabalho através de estabelecimentos agrícolas. O trabalhador livre, visto como preguiçoso, era uma solução 
encontrada para ocupar a vaga deixada pelo escravo, bastava apenas que os proprietários soubessem como incitá-los ao trabalho: boa remuneração (parte que caberia aos proprietários), e leis que assegurassem que fossem cumpridos seus contratos de trabalho (responsabilidade do Estado). Na Região Sudeste, esses trabalhadores foram descartados e substituídos pela mão-de-obra estrangeira.

Quanto aos ingênuos, uns afirmavam que esses trabalhadores não permaneceriam com o mesmo trabalho nas lavouras, preferindo serviços mais leves ou trabalhar por conta própria, oferecendo seus serviços à população. Ao mesmo tempo, o número de ingênuos não seria suficiente para suprir a necessidade de mão-de-obra para a grande lavoura; seriam indolentes como os escravos e não seriam confiáveis, uma vez que, recebendo oportunidade melhor em outro serviço, abandonariam seu trabalho. Os que viam com bons olhos essa mão-de-obra, também concordavam em educá-los para o trabalho agrícola, juntamente com leis coercitivas.

Portanto, se as "qualidades intrínsecas" a cada tipo de trabalhador são consensuais, a polêmica girava em torno de qual dos problemas colocados por estes distintos trabalhadores vale a pena ser enfrentado no sentido de constituir um mercado de trabalho livre. Ou seja, as discussões [acerca do caminho a ser adotado] revelam as necessidades de adaptação e mudanças na sociedade brasileira que caminhava, inevitavelmente, para o mundo do trabalho livre. O que se discute é qual a forma de transição, qual o caminho a ser trilhado:

Através das diferentes propostas de organização do trabalho e da utilização de tal ou qual trabalhador, percebe-se a existência de projetos conflitantes que estão diretamente associados às características regionais, à sua capacidade de transição ao mundo do trabalho livre e à dinâmica da transição capitalista em curso ${ }^{21}$.

Esse caminho devia ser trilhado apenas por imigrantes? Europeus e asiáticos? Não devemos nos esquecer que o trabalhador nacional, livre e assalariado, estava disponível em boa parte do Brasil. A mão-de-obra nordestina, por exemplo, preferiu para a segunda metade do século XIX, migrar para o Norte, atraídos pelo látex e as riquezas que ele poderia trazer. Apesar das dificuldades enfrentadas também por esse trabalho, era preferível arriscar nessa empreitada. O trabalhador nacional foi preterido pelos europeus usando-se as mesmas características tão apreciadas pela maioria do governo e dos grandes proprietários: dócil, obediente e laborioso.

Mas o próprio conceito de trabalhador nacional é bastante complexo. Para Denise Moura (1996), a definição desse termo é difusa. Segundo esse conceito, o trabalhador nacional poderia significar tanto o brasileiro pobre e livre e que nunca teve a experiência do 
cativeiro, quanto os forros, libertos e os filhos de imigrantes. As atitudes e olhares sobre o trabalhador nacional também tinha significados diferentes.

\begin{abstract}
Focalizando as possíveis atitudes e opções do nacional livre em relação ao trabalho livre e remunerado que se definia na província paulista, resgatando a maneira dele vivenciar e lidar com este processo, podemos, por exemplo, dialogar com as figuras retóricas da vadiagem, indolência e incapacidade, repetidas incessantemente pelo discurso oficial numa maneira de estar atendendo e comunicando modos de ser, agir, pensar, acreditar e escolher. Podemos também conversar mais criticamente com a postura historiográfica que acredita que este segmento manteve-se à parte de todas estas transformações, resistindo em proletarizar-se nas fazendas ${ }^{22}$.
\end{abstract}

Segundo Helenilda Cavalcanti e Isabel Guillen, a resposta para que o trabalhador nacional fosse preterido passava pelas seguintes questões:

Havia, em tese, mão-de-obra nacional em excedente, que poderia ter sido utilizada na região cafeicultora. Entender por que se preteriu o trabalhador nacional em favor do imigrante estrangeiro tem sido uma das questões mais debatidas pela historiografia. Explicações de cunho variado foram apontadas para justificar a inviabilidade da utilização dessa mão-de-obra, principalmente a da região Nordeste. Apontaram-se os custos do transporte entre as regiões e, sobretudo, a dificuldade de se arregimentar esse trabalhador, como ainda a forte oposição da elite local com relação à transferência para o sul desse contingente populacional, que significava perda de mão-de-obra local e, conseqüentemente, de poder político. Todavia, a razão maior que norteou a não-aceitação dessa mão-de-obra nacional foi a considerada pela lucratividade do trabalhador estrangeiro, por ser subsidiado, substituindo, de forma compensatória, o escravo no processo produtivo ${ }^{23}$.

Ressaltemos que houve um fluxo migratório no século XIX em direção à Amazônia atraídas pelo ciclo da borracha ${ }^{24}$. Se no Nordeste a pressão demográfica e a alta concentração fundiária eram elementos que estimulavam a imigração para outras regiões, o Sul do Brasil não fazia parte dos planos dos nordestinos, ao menos enquanto a borracha estava mais próxima - fato que muda no início do século XX, onde o trabalhador nacional passa a ser visto como ordeiro e pacífico e facilmente adaptado às duras condições das fábricas e da ordem que surgia.

Com a expansão do café em São Paulo não foram unicamente as grandes propriedades responsáveis pela sua produção. Pequenas e médias propriedades também contribuíram para o avanço dos cafezais nessa região. A economia de alimentos e a produção agroexportadora caminharam lado-a-lado constituindo em fonte de lucro e ordenando o mercado de trabalho. Dizer então que São Paulo era uma região voltada para a exportação e formada por grandes propriedades não se constitui, segundo a historiografia recente, como únicas. Do mesmo modo, os braços europeus não eram a maioria, existindo um excedente de mão-de-obra livre nacional que foi utilizada nessa região. 
(...) boa parte dos trabalhadores era constituída por trabalhadores nacionais, migrantes, que ombreavam o trabalho da lavoura com escravos, segmento este em número bem menor que o existente em regiões cuja economia estruturou-se sobre a grande propriedade. A disponibilidade desta mão-de-obra livre, tradicionalmente ligada à economia de consumo, tornou desnecessária a importação de braços europeus para a região, conforme avançava a desagregação do escravismo e ganhava força a política imigrantista do novo oeste paulista. Diante desta constatação, é possível afirmar que na história da transição da escravidão ao trabalho livre, mesmo no interior da Província de São Paulo é possível identificar zonas de exceção no que diz respeito à introdução do trabalhador imigrante europeu, vale dizer, regiões produtoras de café para o mercado externo que não optaram de pronto por este trabalhador, recorrendo aos trabalhadores livres nacionais, engajados simultaneamente nas tarefas da cafeicultura, cultura de alimentos, produção de açúcar e aguardente, criação de gado e outras profissões ${ }^{25}$.

Diante dessa situação, as especificidades que durante muito tempo se acreditava na historiografia podem ser repensadas. A falta de trabalhadores nacionais no sul do Brasil não ocorreu - ao menos da forma como se acreditavam. Mas controlar essa mão-de-obra, seja nacional ou estrangeira, libertos e ex-escravos era uma preocupação constante do governo e dos grandes proprietários, independentemente dessa mão-de-obra ser assalariados ou proprietários de seus lotes de terras.

O que se percebe ao olhar o século XIX e o início do XX é que nunca houve um grupo ou uma região preferida para imigrar ao Brasil. Houve sim interesses conflitantes e, muitas vezes divergentes sobre quem seria o trabalhador mais indicado. Sobre as pretensas necessidades que haviam nas diferentes áreas do país, o que se considerava obediente, dócil e laborioso era, na verdade, uma nova roupa para a escravidão que vivia o Brasil durante mais de 300 anos e que estava escapando por entre os dedos.

\section{Notas}

${ }^{1}$ COX, Maria Inês. P. \& ASSIS-PETERSON, Ana. A. Transculturalidade e Transglossia: Para Compreender o Fenômeno das Fricções Linguístico-Culturais em Sociedades Contemporâneas sem Nostalgia. In: CAVALCANTI, Marilda. C. \& BORTONI-RICARDO, Stela. M. (Orgs.). Transculturalidade, Linguagem e Educação. Campinas: Mercado de Letras, 2007, p. 30.

${ }^{2}$ HOBSBAWM, Eric. A era dos impérios - 1875-1914. Rio de Janeiro: Paz e Terra, 2005.

${ }^{3}$ CONTIER, Arnaldo Darya. Imprensa e ideologia em São Paulo, 1822-1842: matizes do vocabulário político e social. Petrópolis: Vozes, 1979, p. 145.

4 ALENCASTRO, Luiz Felipe. O trato dos viventes: formação do Brasil no Atlântico Sul. São Paulo: Companhia das Letras, 2000, p. 516.

${ }^{5}$ LOURENÇO, Fernando Antonio. Agricultura Ilustrada - Liberalismo e escravismo nas origens da questão agrária brasileira. Campinas: Editora Unicamp, 2001, p. 141.

${ }^{6}$ NETO, Edgard Ferreira. História e Etnia. IN: CARDOSO, Ciro Flamarion e VAINFAS, Ronaldo. Domínios da História. Rio de Janeiro: Campus, 1997. p. 317.

${ }^{7}$ ROCHE, Jean. A colonização alemã e o Rio Grande do Sul. Porto Alegre: Globo, 1969, p. $91 .$.

${ }^{8}$ PETRONE, Maria Thereza. O imigrante e a pequena propriedade (1824-1930). São Paulo: brasiliense, 1982, p. 22. 
${ }^{9}$ IOTTI, Luiza Horn. Imigração e Colonização - Legislação de 1747-1915. Caxias do Sul: Educs, 2001, p. 23.

${ }^{10}$ Lei Imperial $n^{\circ} 514$, artigo 16 de 28 de outubro de 1848.

${ }^{11}$ PETRONE, Maria Thereza. O imigrante e a pequena propriedade (1824-1930). São Paulo: brasiliense, 1982, p. 263.

12 DENZEM, Rogério. Matizes do "Amarelo" - A gênese dos discursos sobre os orientais no Brasil (18781908). São Paulo: Associação Editorial Humanitas, 2005, p. 60.

${ }^{13}$ LESSER, Jeffrey. A negociação da identidade nacional - Imigrantes, minorias e a luta pela etnicidade no Brasil. São Paulo: Editora Unesp, 2001, p. 155.

${ }^{14}$ NOGUEIRA, Arlinda Rocha. A imigração japonesa para a lavoura cafeeira paulista (1908 - 1922). São Paulo: Instituto de Estudos Brasileiros - USP, 1973, p. 52.

${ }^{15}$ LESSER, Jeffrey. A negociação da identidade nacional - Imigrantes, minorias e a luta pela etnicidade no Brasil. São Paulo: Editora Unesp, 2001, p. 64.

${ }^{16}$ LESSER, Jeffrey. A negociação da identidade nacional - Imigrantes, minorias e a luta pela etnicidade no Brasil. São Paulo: Editora Unesp, 2001, p. 154.

${ }^{17}$ Jornal Correio Paulistano. São Paulo, 5 de março de 1895, p. 1.

${ }^{18}$ ROMERO, Sylvio. O allemanismo no Sul do Brasil - Seus perigos e os meios de os conjurar. Rio de Janeiro: Typographia Heitor Ribeiro, 1906, p. 8.

${ }^{19}$ Idem, p. 15.

${ }^{20}$ LESSER, Jeffrey. A invenção da brasilidade - identidade nacional, etnicidade e políticas de imigração. São Paulo: Editora Unesp, 2015, p. 24.

${ }^{21}$ LANNA, Ana Lúcia. A transformação do Trabalho. Campinas: Unicamp, 1988, p. 64.

${ }^{22}$ MOURA, Denise Aparecida. Cotidiano, trabalho e pobreza em tempos de transição: Campinas, 1850-1888. Cadernos CERU, série 2, no 7, p. 113-121, 1996, p. 115.

${ }^{23}$ CAVALCANTI, Helenilda \& GUILLEN, Isabel. Atravessando fronteiras: movimentos migratórios na história do Brasil. Revista Imaginário - América Latina. № 7, São Paulo, p. 1-4, 2002, s/p. [Link]

${ }^{24}$ GUILLEN, Isabel Cristina Martins. Errantes da Selva. Histórias da migração nordestina para a Amazônia. Tese. Campinas: Unicamp, 1999 e LEROY, Jean Pierre. Uma chama na Amazônia. Petrópolis: Vozes, 1991.

${ }^{25}$ MOURA, Denise A. Soares. Resenha. Revista História. V.23, no 1-2. São Paulo, p. 263, 2004, p. 263. [Link]

\section{Referências Bibliográficas}

ALENCASTRO, Luiz Felipe. O trato dos viventes: formação do Brasil no Atlântico Sul. São Paulo: Companhia das Letras, 2000.

CAVALCANTI, Helenilda \& GUILLEN, Isabel. Atravessando fronteiras: movimentos migratórios na história do Brasil. Revista Imaginário - América Latina. № 7, São Paulo, p. 1-4, 2002. [Link]

CONTIER, Arnaldo Darya. Imprensa e ideologia em São Paulo, 1822-1842: matizes do vocabulário político e social. Petrópolis: Vozes, 1979.

COX, Maria Inês. P. \& ASSIS-PETERSON, Ana. A. (2007). "Transculturalidade e Transglossia: Para Compreender o Fenômeno das Fricções Linguístico-Culturais em Sociedades Contemporâneas sem Nostalgia". In: CAVALCANTI, Marilda. C. \& BORTONI-RICARDO, Stela. M. (Orgs.). Transculturalidade, Linguagem e Educação. Campinas: Mercado de Letras.

DENZEM, Rogério. Matizes do "Amarelo" - A gênese dos discursos sobre os orientais no Brasil (1878-1908). São Paulo: Associação Editorial Humanitas, 2005.

GUILLEN, Isabel Cristina Martins. Errantes da Selva. Histórias da migração nordestina para a Amazônia. Tese. Campinas: Unicamp, 1999.

HOBSBAWM, Eric. A era dos impérios - 1875-1914. Rio de Janeiro: Paz e Terra, 2005.

IOTTI, Luiza Horn. Imigração e Colonização - Legislação de 1747-1915. Caxias do Sul: Educs, 2001. 
KUWAE, Luiza Hiroko Yamada. Cem anos de imigração japonesa: a construção midiática da identidade do imigrante japonês. Universidade de Brasília, 2013.

LANNA, Ana Lúcia. A transformação do Trabalho. Campinas: Unicamp, 1988.

LEROY, Jean Pierre. Uma chama na Amazônia. Petrópolis: Vozes, 1991.

LESSER, Jeffrey. A invenção da brasilidade - identidade nacional, etnicidade e políticas de imigração. São Paulo: Editora Unesp, 2015.

LESSER, Jeffrey. A negociação da identidade nacional - Imigrantes, minorias e a luta pela etnicidade no Brasil. São Paulo: Editora Unesp, 2001

LOURENÇO, Fernando Antonio. Agricultura Ilustrada - Liberalismo e escravismo nas origens da questão agrária brasileira. Campinas: Editora Unicamp, 2001.

MOURA, Denise A. Soares. Resenha. Revista História. V.23, nº 1-2. São Paulo, p. 263, 2004. [Link]

MOURA, Denise Aparecida. Cotidiano, trabalho e pobreza em tempos de transição: Campinas, 1850-1888. Cadernos CERU, série 2, no 7, p. 113-121, 1996.

NETO, Edgard Ferreira. História e Etnia. IN: CARDOSO, Ciro Flamarion e VAINFAS, Ronaldo. Domínios da História. Rio de Janeiro: Campus, 1997.

NOGUEIRA, Arlinda Rocha. Companhias interessadas na introdução de asiáticos em SãoPaulo nos primeiros anos da República. São Paulo: Centro de Estudos Nipobrasileiros, 1979.

A imigração japonesa para a lavoura cafeeira paulista (1908 - 1922). São Paulo: Instituto de Estudos Brasileiros - USP, 1973.

PETRONE, Maria Thereza. O imigrante e a pequena propriedade (1824-1930). São Paulo: brasiliense, 1982.

ROCHE, Jean. A colonização alemã e o Rio Grande do Sul. Porto Alegre: Globo, 1969.

ROMERO, Sylvio. O allemanismo no Sul do Brasil-Seus perigos e os meios de os conjurar. Rio de Janeiro: Typographia Heitor Ribeiro, 1906.

SCHWARZ, Lilia Moritz. O espetáculo das raças. Cientistas, Instituições e questões raciais no Brasil, 1870-1930. São Paulo: Cia. Das Letras, 1993. 